\title{
Вязано-паяные проволочные сетки для молниезащиты композитных ветролопастей
}

\section{Knitted soldered wire meshes for lightning protection of composite wind blades}

\section{Л. Р. Вишняков}

ООО «НПЦ «Увиком» (углеродные волокна и композиты)

\section{R. Vishnyakov}

UVICOM Co Ltd. (Carbon Fibers and Composites)

Поступила в редакцию 18.07.2019, принята к печати - 18.08.2019

\section{Абстракт}

Рассмотрена возможность молниезащиты композитных лопастей ветрогенераторов от прямых ударов молнии путём применения проволочных медных сеток. Предложено использовать в молниеприёмнике и шине-молниеотводе лопастей проволочные сетки трикотажной структуры. В молниеприёмнике рекомендовано применять вязано-паяные сетки с реализацией эффекта диссипации энергии. В шинах-токоотводах использование вязано-паяной сетки создаёт эффект индуктивности, который может защитить композит от чрезмерного нагрева и разрушения.

\section{Abstract}

The possibility of lightning protection of composite blades of wind generators from direct lightning strikes through the use of wire copper nets is considered. It is proposed to use wire nets of knitted structure in the lightning receiver and the lightning rod of the blades. It is recommended to use knitted-soldered nets with the implementation of the effect of energy dissipation in the lightning receiver. In lightning rods, the use of a knitted-soldered nets creates an inductance effect that can protect the composite from excessive heating and destruction.

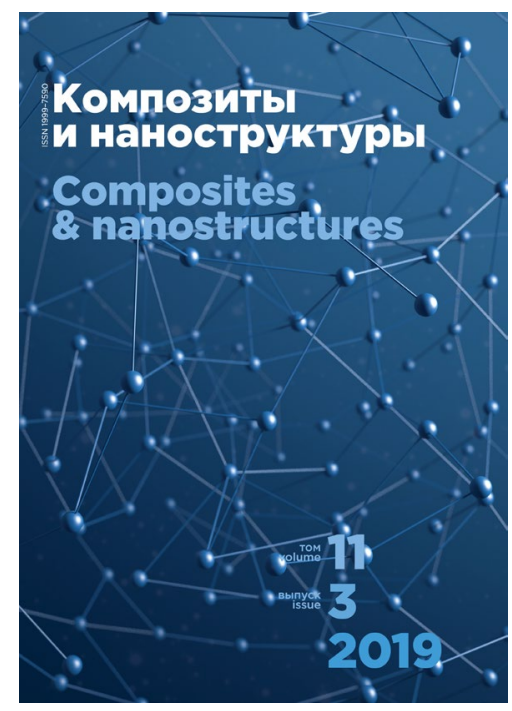

